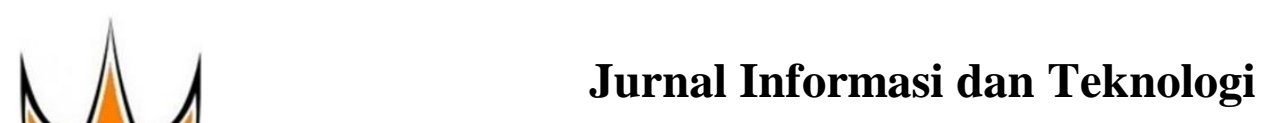

http://www.jidt.org

2021 Vol. $3 \quad$ No. $3 \quad$ Hal:109-114 ISSN: 2714-9730 (electronic)

\title{
Prediksi dan Klasifikasi Buku Menggunakan Metode Backpropagation
}

\author{
R. Rahmiyanti ${ }^{1 \bowtie}$, Sarjon Defit ${ }^{2}$, Yuhandri Yunus ${ }^{3}$ \\ ${ }^{1}$ SMP Negeri 2 Lengayang \\ ${ }^{2,3}$ Universitas Putra Indonesia YPTK Padang \\ rahmiyanti195@gmai1.com
}

\begin{abstract}
Students of SMP Negeri 2 Lengayang have different interests in determining the books they are interested in, so that the library often has difficulty determining the books that are most entered by students, this is because they have not used the right system in determining the type and number of books, only based on the estimated number. Students and subjects only, as a result school students stock books of the books they want to borrow. Based on the above, a method is needed to predict and classify the amount of book stock in the future. The data used is a recap of monthly book lending, from 2018 to 2020 in the third month, with a total of 1653 transactions and 5 types of books processed, then the data is analyzed using the Backpropogation method. The results obtained are using a 5-3-1 pattern with a learning rate of 0.01 , a goal of 0.01 , the number of input units for the Weapon layer 5, the number of units in the hidden layer and the number of output layer units that are placed on 1 layer, and to carry out training using two phases namely feedforward and backpropagation phases. It is removed from this research that the backpropagation method can provide a classification prediction of the number of books that must be provided in the following year based on the number of data entered or the number of data entered.
\end{abstract}

Keywords: Prediction, Book Classification, Backpropagation Method, Feed Forward, Students SMP Negeri 2.

\begin{abstract}
Abstrak
Siswa SMP Negeri 2 Lengayang memiliki kecerungan minat yang berbeda dalam menetukan buku yang mereka minati, sehingga pihak perpustakaan sering kesulitan menetukan buku yang paling banyak disukai oleh siswanya, hal tersebut disebabkan karena belum menggunakan sistem yang tepat dalam menentukan jenis dan jumlah buku, baru berdasarkan perkiraan jumlah murid dan mata pelajaran saja, akibatnya murid sering kehabisan stock buku yang ingin mereka pinjam. Berdasarkan hal diatas, dibutuhkan suatu metode untuk memprediski dan mengklasifikasi jumlah stok buku dimasa mendatang. Data yang digunakan adalah rekap peminjaman buku bulanan, mulai tahun 2018 sampai tahun 2020 bulan ke tiga, dengan jumlah keseluruhan 1653 transaksi dan jumlah jenis buku yang diolah sebanyak 5 jenis buku selanjutnya data dianalisa dengan metode Backpropogation. Hasil yang didapatkan menggunakan pola 5-3-1 dengan learning rate 0,01, goal 0,01 , jumlah unit input layer jumlahnya 5, jumlah unit pada hidden layer berjumlah 3 dan jumlah unit output layer berjumlah 1 layer, dan untuk melakukan pelatihan menggunakan dua fase yaitu feed forward dan fase Backpropagation. Disimpulkan dari penelitian ini bahwa metode Backpropagation dapat memberikan prediksi klasifikasi jumlah buku yang harus disediakan pada tahun berikutnya berdasarkan banyaknya data yang dilatih atau banyaknya data input yang dimasukkan.
\end{abstract}

Kata kunci: Prediksi, Klasifikasi Buku, Metode Backpropagation, Feed Forward, Siswa SMP Negeri 2.

\section{Pendahuluan}

Perpustakaan merupakan salah satu sarana pembelajaran yang sangat vital disebuah sekolah. Bagaikan sebuah system tubuh manusia, perpustakaan merupakan jantung sekolah yang berfungsi memompakan informasi yang sangat berguna bagi kelancaran proses pembelajaran dan peningkatan kualitas pembelajaran, baik bagi para guru maupun Kecerdasan Buatan (Artificial Intelligence) merupakan bagi murid. Perpustakaan adalah sebuah institusi yang ilmu komputer yang mempelajari bagaimana melakukan pengelolaan koleksi buku berupa digital menjadikan komputer bisa menyelesaikan pekerjaan maupun non digital, berbentuk tulisan, cetak maupun serupa dan sebaik manusia bahkan bisa lebih baik dari rekaman yang terstruktur menggunakan sistem yang pekerjaan manusia [3]. Tujuan penting akurat guna memenuhi kebutuhan pendidikan, dikembangkannya kecerdasan buatan ialah untuk penelitian, pelestarian, informasi, dan rekreasi membuat sesuatu teknologi ataupun mesin jadi lebih pemustaka [1].
Untuk meningkatkan mutu pendidikan maka diperlukan sistem yang memadai yang lebih terorganisir sehingga mudah diakses oleh pengguna. Sebagai sumber informasi perpustakaan hendaknya menyediakan koleksi bahan pustaka tertulis, cetak dan terekam untuk keperluan pendidikan, penelitian dan rekreasi intelektual bagi masyarakat [2].

cerdas alhasil mempermudah pekerjaan manusia. 
Backpropagation merupakan algoritma pembelajaran Melalui gambaran wacana diatas penulis akan mencoba yang terawasi dan serta umumnya dipakai oleh mempelajari dan melakukan analisa pengujian Perceptron dengan banyak lapisan untuk mengganti menggunakan jaringan syaraaf tiruan dalam bobot-bobot yang terhubung dengan neuron-neuron memprediksi dan mengklasifikasi buku dengan yang terdapat pada lapisan tersembunyinya [4]. menggunakan metode Bacpropagation, adapun Tujuan Backpropagation menggunakan model pembelajaran penelitian ini adalah untuk mengetahui model arsitektur terbimbing yang dapat meminimalisir kesalahan pada sistem JST yang dipakai untuk memprediksi buku apa output yang dihasilkan oleh jaringan karena saja yang sering dipinjam murid dalam kurun waktu menggunakan multilayer konsep [5]. Dalam jaringan tiga tahun terakhir.

Backpropagation, tiap bagian yang berada di lapisan input terhubung dengan tiap bagian di lapisan 2. Metodologi Penelitian tersembunyi [6]. Begitu juga sebaliknya bagian pada lapisan output terhubung bagian dilapisan input [7]. Jaringan Backpropagation merupakan jaringan multilayer karena memiliki banyak lapisan. Bagian lapisan keluaran berasal dari bagian lapisan tersembunyi hal tersebut terjadi karena pola input dijadikan sebagai pola pelatihan [8].

Bacpropogation pada riset terdahulu dipakai untuk mengenali jenis buku yang sangat banyak dipinjam oleh murid serta prediksi jumlah persediaan dan informasi pengelompokan jenis buku, hasilnya bisa menggambarkan rekemondasi tipe buku apa saja yang hendak direstock bersumber pada jenis buku. Hasil dari pengujian didapatkan tingkat error dari hasil data klasifikasi dan target, selanjutknya dalam uji regresi diketahui siqnifikasi hubungan klasifikasi, target, dan prediksi [9]. Penelitian lain yaitu tentang prediksi ketidaktepatan waktu lulus mahasiswa hal tersebut menyebabkan jumlah kelulusan tepat waktu lebih rendah tiap tahunnya. Sehingga prediksi kelulusan mahasiswa yang tepat dapat membantu program studi untuk membuat keputusan yang tepat dalam mencegah keterlambatan kelulusan mahasiswa [10].

Penelitian lain tentang JST adalah prediksi jumlah pengguna internet terbanyak di dunia. penelitian ini digunakan untuk mengetahui siapa saja yang mengakses internet yang terbanyak di 25 Negara [11]. Penelitian lain yaitu Analisis Algoritma Bacpropagation prediksi nilai ekspor juta USD dengan tingkat akurasi $100 \%$ [12]. Implementasi Metode Backpropagation untuk Memprediksi Tingkat Kelulusan Uji Kompetensi Siswa dengan tingkat akurasi terbaik menggunakan pola 5-6-1 mencapai 95\% [13].

Metode penelitian yang akan diterapkan adalah metode penelitian ilmiah, untuk menjadikan penelitian ini lebih terarah maka bisa dilihat melalui Gambar 1 kerangka kerja.

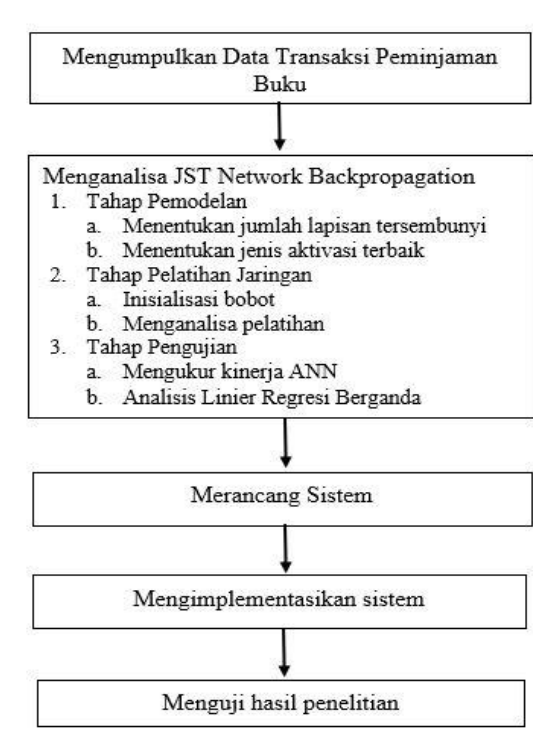

Gambar 1. Kerangka Kerja

\subsection{Mengumpulkan Data}

Langkah selanjutnya adalah mengumpulkan data untuk mendapatkan sebuah informasi yang digunakan untuk menyelesaikan suatu masalah penulis menggunakan teknik kuantitatif dari data transaksi peminjaman buku, sumber data penelitian ini berbentuk data hasil transaksi peminjaman data buku pada perpustakaan SMP Negeri 2 Lengayang tahun 2018 sampai 2020 sampai bulan ke tiga.

Sebagai organisasi publik, perpustakaan dituntut memberikan pelayanan sesuai harapan para penggunanya, yaitu menyediakan informasi yang aktual, manajemen pelayanan diperlukan oleh organisasi untuk meningkatkan kualitas pelayanan. Fungsi petugas perpustakaan salah satunya adalah melayani peminjaman buku bagi pengunjungnya tetapi permasalahan sewaktu menentukan buku apa saja yang paling sering dibutuhkan dan diminati oleh siswa belum terprogram dengan benar dan terencana sehingga pihak perpustakaan masih belum bisa dan mampu untuk memprediksi dan mengklasifikasi buku jenis apa saja yang layak dan banyak diminati oleh siswa ditahun berikutnya.

\subsection{Menganalisa JST Network Bacpropabagiton}

Artificial Neural Network adalah model komputasi pada jaringan syaraf biologis [14]. Dalam melakukan analisa sistem yang dilakukan pada metode Backpropagation untuk memprediksi dan mengklasifikasi buku. Proses metode Backpropagation dilakukan dengan mendefinisikan nilai awal untuk seluruh variabel yang diperlukan seperti menentukan jumlah lapisan tersembunyi, menentukan jenis aktivasi terbaik, menginisialisasi bobot, menganalisa pelatihan, mengukur kinerja ANN, dan menganalisis linier regresi berganda [15].

Jurnal Informasi dan Teknologi Vol. 3 No. 3 (2021) 109-114 


\subsection{Merancang Sistem}

Perancangan bertujuan untuk memberi gambaran yang jelas mengenai program aplikasi yang digunakan. Program aplikasi yang akan dibuat yaitu sistem yang dapat memprediksi buku apa saja yang sering dipinjam dan dibutuhkan oleh siswa. Sistem yang akan dibuat menggunakan metode JST Backpropagation yang mengambil studi kasus di SMP Negeri 2 Lengayang.

\subsection{Mengimplementasikan Sistem}

Pada tahap ini dilakukan implementasi dari rancangan dimana $\mathrm{M}^{\prime}$ adalah hasil normalisasi data, $\mathrm{M}$ adalah data JST dengan metode Backpropagation Selanjutnya yang hendak di normalisasi, sementara a adalah data dilakukan pengolahan data menggunakan laptop nilai terkecil, dan b adalah data nilai terbesar. Data dengan spesifikasi hadrware dan software pendukung.

\subsection{Pengujian Hasil Penelitian}

bentuk numerik 0 sampai 1 . Hal ini dikarenakan jaringan menggunakan fungsi aktivasi Sigmoid Biner (logsig) yang range nilainya dari 0 sampai 1 . Data Buku yang akan digunakan sebagai data Buku sebelumnya harus melalui prosedur normalisasi. Prosedur normalisasi menggunakan persamaan seperti dibawah ini:

$M^{\prime}=\frac{0.8(M-a)}{b-a}+0.1$

buku setelah normalisasi disajikan pada Tabel 2 .
Tabel 2. Data Buku Setelah Normalisasi

Tahap pengujian nantinya akan dilakukan dengapo Tahun aplikasi Matlab 2018 Selanjutnya hasil tersebut dibandingkan dengan melakukan pengujian terhadap data manual.

\section{Hasil dan Pembahasan}

Pada pembahasan hasil penelitian ini dilakukan dengan tahapan pengumpulan data terlebih dahulu, berikutnya dan dilanjutkan analisis neural network Backpropagation.

\subsection{Input Data} Data yang diolah yaitu data jumlah transaksi
peminjaman buku mulai dari tahun 2018 sampai tahun 2020 bulan ke tiga di SMP Negeri 2 Lengayang.

\subsection{Proses Pembagian Data} Data masukan dibagi menjadi data latih (training) dan
data uji (testing). Data dari tahun 2018 sampai tahun 2019 akan dijadikan data latih sedangkan data tahun 2020. Data latih akan dilatih dengan metode Backpropagation akan dijadikan sebagai acuan untuk mengetahui prediksi peminjaman buku di perpustakaan. Data uji adalah data yang akan digunakan sebagai penguji jaringan hasil pelatihan. Dari hasil pengujian akan diketahui tingkat akurasi dari hasil program yang telah dibuat. Pada metode Backpropagation target atau kelas output harus ditentukan terlebih dahulu. Output atau target yang dihasilkan adalah prediksi peminjaman buku. Data rekap disajikan pada Tabel 1.

Tabel 1. Data Rekap Peminjaman Buku Per Tahun

\begin{tabular}{ccccccc}
\hline \multirow{2}{*}{ No } & \multirow{2}{*}{ Tahun } & \multicolumn{5}{c}{ JENIS KLASIFIKASI BUKU } \\
\cline { 3 - 7 } & & Buku & Buku & Buku & Buku & Buk \\
Fiksi & Panduan & Pengayaan & Paket & Referensi \\
\hline 1 & 2018 & 140 & 156 & 90 & 356 & 134 \\
2 & 2019 & 43 & 42 & 52 & 249 & 23 \\
3 & 2020 & 34 & 46 & 59 & 202 & 27 \\
\hline
\end{tabular}

3.3.Melakukan Normalisasi Data

Tujuan Normalisasi adalah untuk mencegah jaringan mengalami kegagalan ketika proses pelatihan dan pengujian dilakukan. Agar data dapat dikenali oleh JST, maka data tersebut harus dipresentasikan dalam

\begin{tabular}{lllllll} 
& \multicolumn{1}{c}{ Tahun } & $(\mathbf{B 2})$ & $\mathbf{( B 3 )}$ & $\mathbf{( B 4 )}$ & $\mathbf{( B 5 )}$ & $(\mathbf{Y})$ \\
2018 & 0.3811 & 0.4195 & 0.2610 & 0.9000 & 0.3667 & 0.9016 \\
2019 & 0.1480 & 0.1456 & 0.1697 & 0.6429 & 0.1000 & 0.1618 \\
2020 & 0.1264 & 0.1553 & 0.1865 & 0.5300 & 0.1096 & 0.0968
\end{tabular}

3.4 Melakukan Iterasi Pertama Hingga Iterasi Terakhir pada Data Pelatihan

Dalam tahapan ini data yang telah diperoleh diaplikasikanterhadap algoritma Backpropagation menggunakan fungsi aktivasi sigmoid. Adapun langkah-langkah pada metode Backpropagation adalah:

a. Tahap initialization

Tahapan ini untuk mendefenisikan nilai awal yaitu apa saja variabel-variabel yang diperlukan, seperti nilai input, weight, output yang diinginkan, learning rate, dan sebagainya.

b. Tahap activation

Ada dua kegiatan yang dilakukan di tahap ini pertama menghitung actual output pada hidden layer dan menghitung actual output pada output layer.

c. Tahap weight training

Ada dua kegiatan yang dilakukan tihapa ini pertama menghitung error gradient pada output layer dan yang kedua menghitung error gradient pada hidden layer.

d. Tahap Iteration

Pada tahap ini yang dilakukan adalah melakukan pengujian dimana jika error yang diharapkan belum juga ditemukan maka kembali ke tahap kedua yaitu tahap activation.

Data baru bisa dikenali dan baru bisa diproses dengan perangkat lunak apabila data sudah dalam bentuk matrik dan numerik, di tahap ini data yang telah didapatkan akanditerapkan pada tahapan algoritma Backpropagation menggunakan fungsi aktivasi sigmoid. Data atau variabel masukan yang akan digunakan sebagai proses analisa disajikan pada tabel 3.

Jurnal Informasi dan Teknologi Vol. 3 No. 3 (2021) 109-114 


\begin{tabular}{cccc}
\hline & \multicolumn{3}{c}{ Tabel 3. Variabel Masukan } \\
\hline No & Variabel & Keterangan & Nilai Input \\
\hline 1 & $\mathrm{~B}_{1}$ & Buku Fiksi & Nilai desimal \\
2 & $\mathrm{~B}_{2}$ & Buku Panduan & Nilai desimal \\
3 & $\mathrm{~B}_{3}$ & Buku Pengayaan & Nilai desimal \\
4 & $\mathrm{~B}_{4}$ & Buku Paket & Nilai desimal \\
5 & $\mathrm{~B}_{5}$ & Buku Referensi & Nilai desimal \\
\hline
\end{tabular}

menentukan parameter jaringannya, dan parameter yang peneliti pakaiadalah sebagai berikut:

3.5 Melakukan Pelatihan dan Menentukan Parameter Jaringan

Arsitektur Jaringan Syaraf Tiruan yang digunakan untuk memprediksi buku yang sering dipinjam adalah Jaringan Syaraf Tiruan Backpropagation terdiri dari:

a. Lapisan Input, dengan 5 simpul masing-masing untuk Klasifikasi data buku pada Buku Fiksi (B1), Buku Panduan (B2), Buku Pengayaan (B3), Buku Paket (B4), Buku Referensi (B5).

b. Lapisan Output, dengan 1 simpul dimana nilai rata (T) sebagai nilai yang dijadikan prediksi untuk menghitung data klasifikasi buku yang sering digunakan.

c. Lapisan Tersembunyi, dengan jumlah simpul yang ditentukan oleh pengguna.

Bentuk arsitektur Jaringan Syaraf Tiruan dapat dilihat pada Gambar 2.

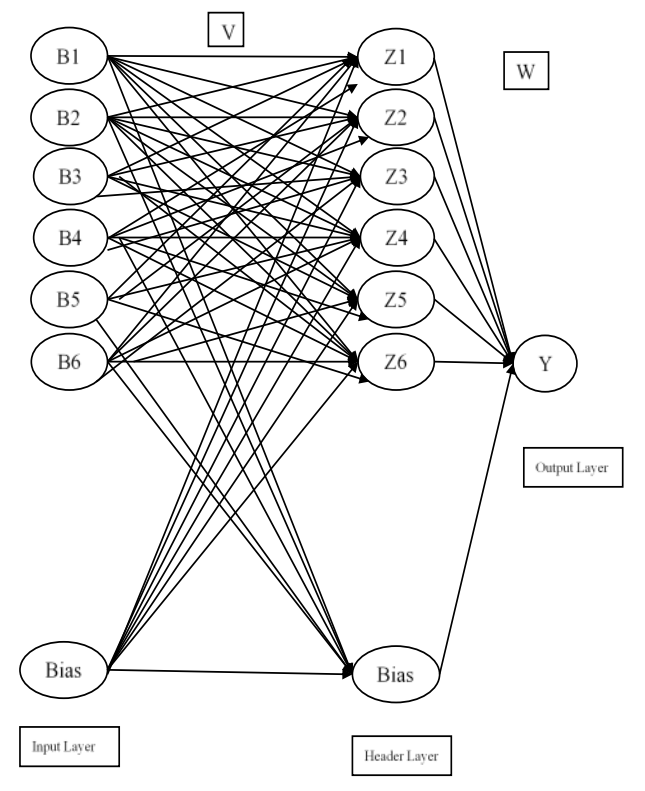

a. Menentukan jumlah hidden layer yaitu 3layer.

b. Menggunakan Epoch antara epoch 1000-5000 dengan kenaikan setiap epochnya 1000.

c. Menggunakan Learning rate (lr) 0.1 dan 0.01 .

d. Menggunakan target error / goal 0.1 dan 0.01 .

Penentuan parameter ini nantinya akan di ujikan pada aplikasi matlab supaya diketahui proses pembelajaran yang terbaik dari setiap percobaan yang dilakukan.

3.6 Melakukan Pengujian

Selanjutnya dilakukan pengujian metode Bacpropagation dengan pola arsitektur 5-3-1, dimana jumlah unit pada input layernya 5 , selanjutnya jumlah unit pada hidden layernya 3 sementara jumlah unit pada output layernya 1 layer, ini dilakukan untuk menghitung nilai pelatihan dengan Jaringan Syaraf Tiruan untuk menentukan pola dari data kalsifikasi buku. Pada kasus ini menggunakan pola 5-3-1 dengan learning rate 0,01 , goal 0,01 . supaya lebih jelas disajikan pada Tabel 4 .

\begin{tabular}{cccccc}
\multicolumn{7}{c}{ Tabel 4. Input Data } \\
\hline NO & (B1) & (B2) & (B3) & (B4) & (B5) \\
\hline 1 & 0.3811 & 0.4195 & 0.2610 & 0.9000 & 0.3667 \\
\hline
\end{tabular}

Setelah hasil transformasi diketahui langkah selanjunya adalah menetapkan nilai input, nilai target, learning rate $(\alpha)$, dan epoch, dibawah ini dilakukan analisa masalah dengan menggunakan arsitektur 5-3-1, dan dilakukan tahap pengujian menggunakan fase feed forward.

\section{Iterasi 1}

Fase Feedforward:

1. Tahap Initialization

Diketahui :

$\begin{array}{ll}\text { B1 } & =0.3811 \\ \text { B2 } & =0.4195 \\ \text { B3 } & =0.2610 \\ \text { B4 } & =0.9000 \\ \text { B5 } & =0.3667\end{array}$

Learning rate $(\alpha)=0,01$

a. Inisiasi bobot dan bias pada hidden layer

Inisialisasi Bobot merupakan tahapan awal yang harus dilakukan dalam membentuk Jaringan Syaraf Tiruan. Karena bobot awal merupakan penghubung simpul pada layer input dan layer tersembunyi. Nilai bobot dan bias ini bisa saja berubah ketika melakukan proses training di aplikasi Matlabyang digunakan. Adapun nilai bobot dan bias disajikan pada Tabel 5 .

Dimana B adalah variabel masukan (Input), $\mathrm{V}$ adalah bobot lapisan tersembunyi, sementara $\mathrm{W}$ adalah bobot lapisan keluaran dan Y Adalah keluaran (Output).

Proses selanjutnya adalah melakukan pelatihan menggunakan Matlab tetapi sebelumnya sudah melakukan normalisasi data terlebih dahulu, langkah awal untuk melakukan proses pelatihan adalah harus 


\begin{tabular}{cccc} 
& & & \\
Tabel 5. Bobot Awal dan Bias dari Input Layer ke & Hidden Layer \\
\hline & 1 & 2 & 3 \\
\hline x1 & 0.3811 & 0.1480 & 0.1264 \\
x2 & 0.4195 & 0.1456 & 0.1553 \\
x3 & 0.2610 & 0.1697 & 0.1865 \\
x4 & 0.9000 & 0.6429 & 0.5300 \\
x5 & 0.3667 & 0.1000 & 0.1096 \\
Bias & 0.9016 & 0.1618 & 0.0968 \\
\hline
\end{tabular}

b. Inisialisasi Bobot pada hidden layer ke output layerDemikian juga dengan bobot awal yang mengaitkan simpul lapisan tersembunyi dan lapisan output (W1, W2, W3, W4, W5) yang dipilih secara acak, ketika menentukan bobot setiap komputer nilainya bisa berubah-ubah. Adapun nilai bobot menuju output layer dapat disajikan pada Tabel 6.

Tabel 6. Bobot dan Bias dari Hidden Layer ke Output Layer

\begin{tabular}{cc}
\hline & $\mathrm{Y}$ \\
\hline $\mathrm{Z} 1$ & 0.9016 \\
$\mathrm{Z} 2$ & 0.1618 \\
$\mathrm{Z} 3$ & 0.0968 \\
Bias & 0.3867 \\
\hline
\end{tabular}

2. Tahap Activation

Melakukan perhitungan dari setiap bobot pada masing-masing layer sesuai dengan fungsi aktivasi sigmoid dengan metode Backpropagation. Adapun langkah-langkahnya sebagai berikut:

a. Setiap unit pada lapisan input layer $(\mathrm{Bi}, \mathrm{i}=$ $1,2,3, \ldots$, p) menerima sinyal Bi dan meruskan ke semua pada lapisan hidden layer.

b. Menghitung semua nilai output pada hidden layer, dengan persamaan dibawah ini:

$$
\begin{aligned}
Z_{-} \text {net }_{j=} V_{j 0} & +\sum_{i=1}^{n} \text { Bi Vji } \\
\text { Z_net }_{1} & =(0.9016)+(0.3811 *(0.3811) \\
& +(0.4195 *(0.4195))+(0.261 *(0.261)) \\
& +(0.9 *(0.9))+(0.3667 *(0.3667)) \\
\text { Z_net }_{1} & =2.2354 \\
\text { Z_net }_{2} & =0.5787 \\
\text { Z_net }_{3} & =0.7189
\end{aligned}
$$

Jadi hasil perhitungan dari nilai output pada hidden layer dengan hasil $Z \_$net $=2.2354, \mathrm{Z} \_$net $2=0.5785$, dan Z_net $3=0.7189$.

Hitung Output aktual pada Hidden Layer menggunakan fungsi aktivasi, dengan persamaan di bawah ini:

$$
\begin{aligned}
Z_{j}=f\left(Z_{\text {net }_{j}}\right)=\frac{1}{1+e^{-z_{-} \text {net } j}} \\
Z 1=f(2.2354)=\frac{1}{1+e^{-(2.2354)}}=0.8094 \\
Z 2=2.3736 \\
Z 3=3.5574
\end{aligned}
$$

Jadi hasil perhitungan dari nilai output pada hidden layer menggunakan fungsi aktivasi dengan hasil $\mathrm{Z} 1=0.8094, \mathrm{Z} 2=2.3736$, dan $\mathrm{Z} 3=$ 3.5574

Jumlahkan semua sinyal yang masuk kedalam unit output dengan persamaan di bawah ini:

$$
y_{\text {net } k}=w_{k o}+\sum_{j}^{p}=1_{Z j W k}
$$

$$
\begin{aligned}
& y_{\text {net } 1}=W 0+(W 1 * Z 1)+(W 2 * Z 2)+(W 3 * Z 3)= \\
& 0.3867+(0.9016 * 0.8094)+ \\
& (0.1618 * 2.3736)+(0.0968 * 3.5574) \\
& y_{\text {net } 1}=0.3867+0.7297+0.3840+0.3443=1.8447
\end{aligned}
$$

Kalkulasikan semua output aktual pada output layerdengan persamaan dibawah ini

$$
\begin{gathered}
y_{j}=f\left(y_{\text {net }_{k}}\right)=\frac{1}{\alpha+e^{-y_{-} \text {net } k}} \\
y_{1}=f\left(y_{\text {net }_{1}}\right)=\frac{1}{1+e^{-(1.8447)}}=0.3516
\end{gathered}
$$

Hasil perhitungan dari semua aktual pada output layer y1 adalah 0.3516 .

\section{Fase Backforward}

\section{Tahap Weigh Training}

Yaitu menjumlahkan error gradient pada output layer berdasarkan nilai kesalahan disetiap unit keluaran, dengan persamaan dibawah ini:

$\delta k=\delta=(t-y) y(1-y)$

$\delta k 1=\delta=(0.1000-0.3516) 0.3516(-0.3516)$

$\delta k 1=(-0.0222)$

Hasil error perubahan output layer dengan nilai $\delta k 1$ $=(-0.0222)$.

Hitung perubahan bobot hidden layer ke output, dengan persamaan dibawah ini:

$$
\begin{aligned}
\Delta w_{k j} & =\alpha \cdot \delta k \cdot Z_{j} \text { denganlearning rate } 0.01(7) \\
& =0.01 *(-0.0222) * 0.8094
\end{aligned}
$$

$\Delta w_{11}=(-0.0001796)$

$\Delta w_{12}=(-0.0005269)$

$\Delta w_{13}=(-0.0007897)$

Hasil akhir dari perhitungan perbandingan buku dapat disimpulkan dengan melakukan proses perhitungan nilai yang masuk pada eror gradient pada output layer dengan nilai adalah -0.0007897

\section{Kesimpulan}

Kesimpulan yang didapatkan dalam rangkaian penelitian ini adalah Jaringan Syaraf Tiruan Backropagation dengan pola 5.3.1 dapat memprediksi klasifikasi buku yang diminati pada tahun yang akan datang. Semoga pada penelitian selanjutnya bisa menambah jumlah data input sehingga data yang dihasilkan lebih akurat. 


\section{Daftar Rujukan}

[1] Yuliana, K., Zahrudin, M., \& Utari, T. (2018). Analisa Sistem Informasi Peminjaman dan Pengembalian Buku Perpustakaan Pada SMA Nusantara 1 Tangerang. SENSI Journal, 4(1), 46-63. DOI: https://doi.org/10.33050/sensi.v4i1.714 .

[2] Siahaan, A. T. A. A. (2018). Analisa Metode Perceptron Prediksi Penyediaan Buku Perpustakaan Sesuai Kebutuhan Mahasiswa (Studi Kasus di Universitas Islam Negeri Sumatera Utara Medan). Algoritma : Jurnal Ilmu Komputer dan Informatika, 2(2)

[3] Rahayu, R. Wihandika, R. C. \& Perdana, R. S. (2018). Implementasi Metode Backpropagation Untuk Klasifikasi Kenaikan Harga Minyak Kelapa Sawit. Jurnal Pengembangan Teknologi Informasi dan Ilmu Komputer, 2(4) 1547-1552.

[4] Ismanto, E., Effendi, N., \& Cynthia, E. P. (2018). Implementation of Backpropagation Artificial Neural Networks to Predict Palm Oil Price Fresh Fruit Bunches. IJISTECH (International Journal of Information System \& Technology), 2(1), 26. DOI: https://doi.org/10.30645/ijistech.v2i1.17 .

[5] Yessa, A. R., \& Hardjianto, M. (2020). Prediction of Water Use Using Backpropagation Neural Network Method and Particle Swarm Optimization. Bit-Tech 2(3).

[6] Putri, D. A., Hananto, B., Afrizal, S., \& Pangaribuan, A. B. (2019). Prediksi Program Studi Berdasarkan Nilai Siswa dengan Algoritma Backpropagation (Studi Kasus SMAN 6 Depok Jurusan IPS). Informatik Jurnal Ilmu Komputer, 15(2).

[7] Windarto, A. P., Lubis, M. R., \& Solikhun, S. (2018). Model Arsitektur Neural Network dengan Backpropogation Pada Prediksi Total Laba Rugi Komprehensif Bank Umum Konvensional. Klik Jurnal Ilmiah Kumpulan Jurnal Ilmu Komputer, 5(2), 147. DOI: https://doi.org/10.20527/klik.v5i2.148
[8] Norhikmah, N., \& Rumini, R. (2020). Klasifikasi Peminjaman Buku Menggunakan Neural Network Backpropagation. Jurnal SISTEMASI, 9(1). DOI: https://doi.org/10.32520/stmsi.v9i1.562 .

[9] Yalidhan, M. D. (2018). Implementasi Algoritma Backpropagation Untuk Memprediksi Kelulusan Mahasiswa. Jurnal Ilmiah Klik Kumpulan Jurnal Ilmu Komputer, 5(2). DOI: https://doi.org/10.20527/klik.v5i2.152 .

[10] Setti, S., Wanto, A., Syafiq, M., Andriano, A., \& Sihotang, B. K. (2019). Analysis of Backpropagation Algorithms In Predicting World Internet Users. Journal of Physics: Conference Series, 1255. DOI: https://doi.org/10.1088/1742-6596/1255/1/012018 .

[11] Saragih, J. R., Saragih, M. B. S., \& Wanto, A. (2018). Analisis Algoritma Backpropagation dalam Prediksi Nilai Ekspor (Juta USD). Jurnal Pendidikan Teknologi dan Kejuruan, 15(2). https://doi.org/10.23887/jptk-undiksha.v15i2.14362.

[12] Syofneri, N., Defit, S., \& Sumijan. (2019). Implementasi Metode Backpropagation untuk Memprediksi Tingkat Kelulusan Uji Kopetensi Siswa. Jurnal Informasi dan Teknologi, 1(4), 12-17. https://doi.org/10.37034/jidt.v1i4.13

[13] Siregar, S. P., \& Wanto, A. (2017). Analysis of Artificial Neural Network Accuracy Using Backpropagation Algorithm In Predicting Process (Forecasting). IJISTECH (International Journal Of Information System \& Technology), 1(1), 34. DOI: https://doi.org/10.30645/ijistech.v1i1.4 .

[14] Hasan, N. F., Kusrini, K., \& Fatta, H. A. (2019). Analisis Arsitektur Jaringan Syaraf Tiruan Untuk Peramalan Penjualan air Minum dalam Kemasan. Jurnal Rekayasa Teknologi Informasi (JURTI), 3(1). DOI: https://doi.org/10.30872/jurti.v3i1.2290 .

[15] Sovia, R., Yanto, M., \& Melati, P. (2020). Prediksi Jumlah Kunjungan Wisata Mancanegara dengan Algoritma Backpropagation. Jurnal Media Informasi Budidarma, 4(2). DOI: http://doi.org/10.30865/mib.v4i2.2048 . 